\title{
Communication Strategies among Inbound Mobility Students
}

Nur Maisarah Roslan, Nur Widad Roslan, Suraya Amiruddin, Siti Nur Aliaa Roslan

To Link this Article: http://dx.doi.org/10.6007/IJARBSS/v11-i9/10144

DOI:10.6007/IJARBSS/v11-i9/10144

Received: 15 July 2021, Revised: 17 August 2021, Accepted: 01 September 2021

Published Online: 24 September 2021

In-Text Citation: (Roslan et al., 2021)

To Cite this Article: Roslan, N. M., Roslan, N. W., Amiruddin, S., \& Roslan, S. N. A. (2021). Communication Strategies among Inbound Mobility Students. International Journal of Academic Research in Business and Social Sciences, 11(9), 1503-1519.

Copyright: (c) 2021 The Author(s)

Published by Human Resource Management Academic Research Society (www.hrmars.com)

This article is published under the Creative Commons Attribution (CC BY 4.0) license. Anyone may reproduce, distribute, translate and create derivative works of this article (for both commercial and non-commercial purposes), subject to full attribution to the original publication and authors. The full terms of this license may be seen at: http://creativecommons.org/licences/by/4.0/legalcode

Vol. 11, No. 9, 2021, Pg. 1503 - 1519

Full Terms \& Conditions of access and use can be found at http://hrmars.com/index.php/pages/detail/publication-ethics 


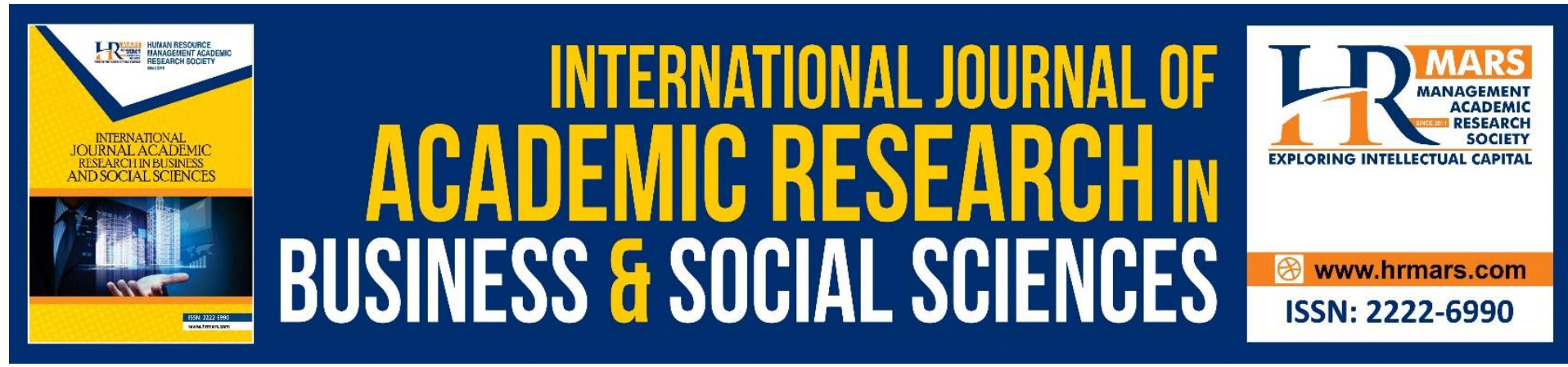

\title{
Communication Strategies among Inbound Mobility Students
}

\section{${ }^{1}$ Nur Maisarah Roslan, ${ }^{2}$ Nur Widad Roslan, ${ }^{2}$ Suraya Amiruddin, ${ }^{3}$ Siti Nur Aliaa Roslan}

${ }^{1}$ 18-G, Al-Madinah International University, HEXA, Pusat Perdagangan Salak 2, Jalan 2/215E, Taman Desa Petaling, Desa Petaling, 57100 Kuala Lumpur, ${ }^{2}$ Faculty of Business, Information and Human Sciences, Infrastructure University Kuala Lumpur, Unipark Suria, Jalan Ikram Uniten, 43000 Kajang, Selangor, Malaysia, ${ }^{3}$ Civil Engineering and Construction Division, Faculty of Engineering Science and Technology, Infrastructure University Kuala Lumpur,

Unipark Suria, Jalan Ikram - Uniten, 43000 Kajang, Selangor, Malaysia

\begin{abstract}
Mobility program has been carried out in universities from all over the world as it is the most popular program among the university students. This is due to the fact that the mobility program will ensure a starter link and communication among universities. The objective of this study was to identify the communication strategies used by the inbound mobility students from the non-speaking English countries in Universiti Putra Malaysia. The samples of the study consisted of 20 respondents and they were 7 male and 13 female mobility students from Asian and European universities who were attending the mobility program at Universiti Putra Malaysia. The methods involved in this study was observation sessions. Observation sessions were video-taped. The study only focuses on the communication strategies used among inbound mobility students and the understanding, opinion and idea of the mobility program to the inbound mobility students at Universiti Putra Malaysia. As for the procedure of the study, the subjects were informed about the observation sessions which were video-taped. An area of topics was given to the subjects to be discussed. This study used Communication Strategies Theory by Dornyei \& Scott (1997). The results of the study showed that there was a large amount of communication strategies used among inbound mobility students at UPM during their conversation discussions. Although the mobility students were able to speak in the English language, it can be said that the language spoken had errors in sending the message across to the listener. It is also believed that the errors made were all common among the inbound students and not much help was given to them to overcome the issues. Therefore, the need to use communication strategies were important to enhance learning. It is hoped that further studies will focus on the long-term inbound mobility program.
\end{abstract}

Keyword: Communication Strategy, Discourse, Inbound Mobility Students, Mobility Program 


\section{Introduction}

The international students participated in the mobility programs offered by the universities. Universities from all over the world have been carrying out mobility program for years since it is one of the most popular programs among university students. This is because such program could lead to a beginning of a relationship and communication among universities. Nonetheless, the students who participated in the mobility program have gotten the opportunity for their experience advancement and pick up a lot more information and knowledge about the universities from the other countries as well as gaining more knowledge about the new culture in the university (Roslan et al., 2018). Besides that, those students who participated in the mobility program will also be able to learn new adventurous experience during their stay as short as one week to four months. During the mobility program abroad, students take courses at the host university and they will be able to get their credit transferred. This is provided that the courses are equivalent and accepted by their home university. Therefore, students will still be able to finish their studies and graduate on time instead of having to extend semesters while they are studying abroad.

Floyd (2008) claimed that a wide range of benefits and outcomes are offered to exchange students who are willing to explore onto the international adventure of new experiences. These are linked together to establish the main exchange program experience. Students exchange program offers a wide range of benefits such as international learning and knowledge that drives them forward towards accepting and acknowledging of a range of cultures and community views, language acquisition is gained through practical involvement, awareness and implementation of substitution, various approach of learning method, analytical and problem solving skills, increased awareness towards global issues and much wider general knowledge and self-development as well as interest that leads to the increased of self-confidence and self-esteem (Roslan et. al., 2018). It can be seen that it is the most obvious change in exchange students who just returned home. Their maturity and selfconfidence are shown by the need to overcome any encounters that are outside of their familiarised support system or comfort zone, being an addition into another family and the growth of friendships that will last a very long time.

On the other hand, the exchange program also showed the appreciation towards their home and family. A remarkable achievement upon completion which inspires students to improve their very own opinions and make well-versed decisions and attempt to reach the goals (Cairns, 2018). Those students involved with the exchange program or so called mobility students who studied at a higher-level will be more comfortable in new surroundings. Potential universities in most countries look favourably at all the experience gained on the students' time living abroad and obtaining various knowledge from another culture as well as learning a new language. There seems to be a greater pressure in communicating while in relations to group dynamic and personal sensitivity towards others awareness development. A successfully completed and accomplished program signifies an excellent extent of flexibility, to which includes being able to reach a settlement, focus and succeed through tough times (Wood, 2010). Students will try their best to communicate well in order for the message to be delivered. This way, communication strategies will take place in order for them to be content with the discussion. 
Nonetheless, the mobility program might not meet its core or main purpose since communication does play an important part of students' life wherever they are in the world. Hence, this research will help to find one of the solutions in communication strategies that can be used among the inbound mobility students in order for them to be successful in communication.

\section{Literature Review}

Communication is a tool used in connecting one person to another. In communication, language plays an important aspect in getting messages across to another person. In this multilingual world, a lot of languages are being used in communication. First, there will be the mother tongue language which comes from these students' origin of culture and country. Then, there are second and third language learned by a lot of people in this world trying to improve themselves in understanding others. Due to that, people tend to travel around the world to gain new experience by studying abroad, learning the culture, foods, believes as well as the new language. Sometimes, communication barrier tends to appear without people realising it. Therefore, communication strategies are created when communicating in order to have a smooth communication without any confusion.

Miscommunication is a barrier between people who are not able to communicate together in the same language. The use of language is an important part of any communication process. For example, people with speech delay or weakness in speech will use sign language, nonverbal communication or brail to communicate with others. The process of communication between people will face difficulties in certain situation whereby they do not understand each other's language. Communication issues is a rhetorical expression used specifically to refer to language barriers in communication, for example, communication issues faced by groups or people who speaks different language, or even in different dialects (Khan, 2017).

According to Khullar (2017), the most common communication issues are language barriers which often cause misinterpretations as well as confusions between people. Not everyone around the world speaks English as their main language to communicate. However, even if they do use English to communicate, it will be their second or third language. The communication between the speaker and the receiver has no meaning if the language or words used to communicate are not the same. The communication becomes ineffective and the message is not being conveyed properly. This normally happens when a person uses words another person does not understand. It is agreeable that the use of two different languages to communicate between two people is the most noticeable and obvious barrier faced by most people since they are not able to understand each other at all. People use different accents as well as dialect (in the use of words also differs) that come from different places within the same area even though they use the same language to communicate. Although the language used is the same, its meaning and interpretations of words used in a sentences may differ by the different dialect and accents, to which will lead to all sort of conflicts between the speaker and the receiver. When communicating, the speaker will need to use the right choice of words in explaining any information. This is because sometimes the words chose by people in showing their agreement or disagreement may be mistaken as sarcasm by others to which will lead to negative thoughts. However, it is preferable to avoid any words that has two meanings as it may confuse the receiver that may lead to misunderstanding or misinterpretation and the message will not be sent as its intention and reacts as a type of language barrier in communication. 
On the other hand, Rhoades (2017) claimed that there should be strategies for mobility students when communicating in order for the other party to understand. However, Rhoades (2017) study showed that mobility students have problem in communication and therefore lead to miscommunication. De Wit \& Hunter (2015) have similar results with Rhoades (2017) and added that due to the importance of internatiolization towards higher education, it is wise to consider the communication strategies used by students to adapt in the learning environment. However, De Wit \& Hunter (2015) study showed that miscommunication exists when mobility students tried their best to speak to another person who does not speak the same language. The same issue faced in a study by Sawir (2012) which showed that international students face confusion during interaction due to misunderstanding from the other speaker. Sawir (2012) also found that the international students need various types of communication strategies in order to understand the message that had been delivered.

Masithoh et al., (2018) claimed in their study that students' linguistic difficulties can be aided through communication strategies. Communication strategies are a big help for students in their fluency in speaking, as they can communicate without borders. The study showed high proficient students were able to utilise higher communication strategies as compared to the low proficient students which lead to the survival of high proficiency level of students to communicate well. However, it is still a huge struggle for the low proficiency students to communicate.

European Erasmus (2018) program results suggested that a more appropriate way to differentiate between Erasmus and non- Erasmus students is not through the financial barriers, but through the personal barriers which helps the students to differentiate between the two. The programs analysis revealed that there is a two-prong approach to increase students' participation, first focusing on giving students better information and communication and the other approach by stressing the Erasmus mobility benefits towards the students.

Communicating effectively towards others can be difficult, and the reason of it being difficult can vary around the world in many situations. However, communication being communication is the most critical issue in a person's everyday lives and it is more important than ever to be capable of it. According to Rochester (2018), the way a person communicate is normally influenced by the main objective the person wants to say, which varies from what and how they want to communicate the information and the body language used when delivering the message. Some of the biggest issues to establish effective communication includes bridging insufficient planning beforehand, lack of audience knowledge, an unclear objective or purpose of the communication, information does not engage well with the audience, the main message or content is not structure properly, weak empathy with the Csuite and most importantly unable to identify the pass lesson learns on communication effectives (Rochester, 2018). Communication should be able to fall into a few purposes such as whether to inform, persuade or a direct communication. Therefore, the right communication strategies are needed during communication in order for the message to get across to the other side of the party. Those are the most common issues faced by most people nowadays which are lack of communication strategies when communicating with others.

Manjet Kaur Mehar Singh (2016) mentioned in her study that an increasing number of international students have chosen Malaysia as their place to study, however with this also 
increases the academic writing difficulties among those international students. This shows that the international students were not prepared for academic writing at a graduate level, as their academic context of their first-degree program results did not reflect on their academic writing results. The study further elaborated that, with the students' academic writing experience, it does not match with their previous academic learning background as compared to their current master's communication of practice. With this, the study showed that the international graduate students find it hard to adjust to their master program of study, especially in the English language, as most of the international student lack on the exposer of the English language from their first-degree that has prepared them to graduate in English. Therefore, Manjet Kaur Mehar Singh (2016) recommended that communicative strategies need to be implemented towards these international students to assist and improve their academic writing practices.

According to Al Hosni (2014), when it comes to learning a language, oral skills do help. However, the actual spoken form of the language shows better outcomes. This is because of the young learner's classroom or the primary platform of learning the language. Without the language exposer, students tend to miss out on the necessary vocabulary items and grammar structures. To overcome such problem, Nakatani (2010) suggested that students and learners improve their speaking ability through learning strategies which need to be developed in order for the students to become more independent.

Foster (2017) study focused on the influence of international mobility students on crosscultural adaptation. The study also looked at the new learning environment from business and design where the learning experiences of students from China studying business in the UK and the students from the UK studying design in China. The two-way process had used the seven themes of adaptation of students' learning style are recognized including perceptions and response to teaching, learning, peers and assessment. The results of the study discovered that each learning style shows an essential role in helping effective engagement with learning in the new learning environment. Therefore, the study proposed a guideline for systematic, pre-mobility, intercultural skills development to guarantee maximum benefits from studying abroad. Foster (2017) also claimed that the internalization of the mobility students will help both the students as well as the universities involved. Foster's (2017) study is parallel to the study of Adnett (2010), Bagnoli (2009), Beech (2014), Brooks \& Waters (2010) and Brooks \& Waters (2011) where internalization in the mobility program will help in the process of adapting in different cultures and maximize learning experience.

Based on the research problems mentioned by previous studies as stated above, the objective of this study is to investigate the communication strategies used among inbound mobility students at Universiti Putra Malaysia.

\section{Methodology}

This study used qualitative method in order to analyse the data. Quantitative data as in the numbers of strategies used for each subject were discussed from the data obtained. The study focused on the inbound mobility students studying at Universiti Putra Malaysia, who were involved with the mobility program from Asian and European universities. The program involved the exchange students from the bachelor program. The exchange students will have to deal with other mobility students, local students and lecturers. 
The sample of the study consisted of 7 male and 13 female respondents at the age between 20 to 30 years old. They were selected from the mobility programs at Universiti Putra Malaysia. The respondents were randomly chosen. Respondents were from a country that does not use English as their first language to communicate daily. Therefore, the English language proficiency subject that they were involved in was at the level of intermediate and low. The respondents' self-confirmed that their level of English language proficiency was low too. However, this study did not take into account the English language proficiency. In this study, there were only 20 respondents' cases found based on the subjects' background of origin. Only a small number were managed as the number of inbound mobility students were decreasing due to the visa issues as well as the world health issues.

The study was taken place at Universiti Putra Malaysia. The respondents were attached to the Basic Malay Language class at Centre for the Advancement of Language Competence (CALC), Universiti Putra Malaysia. The respondents were bachelor students from different programs. The respondents' language proficiency was not taken into account in this study.

The method used in this study was observation. The participants were informed of the study and the video tape was used during the class. The subjects were also given a topic in order to have a smooth conversation between the two parties about their opinions on mobility program. The interview session took place for 30 minutes for each set of students. A clearer description or discussion of the transcription method used, data coded and sampling techniques are identified as below:

\begin{tabular}{|c|c|c|}
\hline Items & & Code \\
\hline Subject & & $\mathrm{S} 1-\mathrm{S} 20$ \\
\hline $\begin{array}{l}\text { Communication } \\
\text { strategy }\end{array}$ & $\begin{array}{l}\text { Avoidance strategy: Message } \\
\text { Abandonment }\end{array}$ & CS1 \\
\hline & $\begin{array}{l}\text { Avoidance strategy: Topic } \\
\text { Avoidance }\end{array}$ & CS2 \\
\hline & $\begin{array}{l}\text { Compensatory strategy: } \\
\text { Circumlocution }\end{array}$ & CS3 \\
\hline & $\begin{array}{l}\text { Compensatory strategy: } \\
\text { Approximation }\end{array}$ & CS4 \\
\hline & $\begin{array}{l}\text { Compensatory strategy: Use of all- } \\
\text { purpose words }\end{array}$ & CS5 \\
\hline & $\begin{array}{l}\text { Compensatory strategy: Word } \\
\text { coinage }\end{array}$ & CS6 \\
\hline & $\begin{array}{l}\text { Compensatory strategy: } \\
\text { Prefabricated patterns }\end{array}$ & CS7 \\
\hline & $\begin{array}{l}\text { Compensatory strategy: } \\
\text { Nonlinguistic signals }\end{array}$ & CS8 \\
\hline & $\begin{array}{l}\text { Compensatory strategy: Literal } \\
\text { translation }\end{array}$ & CS9 \\
\hline & Compensatory strategy: Foreignizing & CS10 \\
\hline & $\begin{array}{l}\text { Compensatory strategy: Code- } \\
\text { switching }\end{array}$ & CS11 \\
\hline & $\begin{array}{l}\text { Compensatory strategy: Appeal for } \\
\text { help }\end{array}$ & CS12 \\
\hline
\end{tabular}




\begin{tabular}{|l|l|l|}
\hline & $\begin{array}{l}\text { Compensatory strategy: Stalling or } \\
\text { time gaining strategies }\end{array}$ & CS13 \\
\hline
\end{tabular}

Table 1: Transcription Method Used, Data Coded and Sampling Techniques

Observation sessions were done during the Basic Malay Language class. Observation is focused on the communication strategies used by inbound mobility students when communicating with others. Based on the observation, a list of repertoire is obtained. The observation sessions were semi structured. A specific topic was given to the students based on the focus of the research.

1. Students will be observed on their conversation about the mobility program.

2. A topic is given on students' opinions on the mobility program.

3. The focused topic given were based on the current situation faced by the inbound mobility student solely. The topic is original and not modified or adapted from any other studies.

4. It is not necessary for all the questions to be asked between the students during the conversation as to ensure the authenticity of the conversation and not to make it look like a scripted conversation.

5. Video recording were used during the observation session during the class sessions.

As for the procedure of the study, the subjects were informed about the observation session that will be carried out and video-taped during the class session. Topics were given based on the focus of the study. This study will be using Communication Strategies Taxonomy by Dornyei \& Scott (1997) to analyse the data. Data of the conversation will be transcribed and communication strategies used by the subjects will be identified according to the examples and explanation given by Dornyei \& Scott (1997).

\section{Results and Discussion}

Communication Strategies among Inbound Mobility Students towards Mobility Program at Universiti Putra Malaysia (Dornyei \& Scott, 1997)

Dornyei \& Scott (1997) explained that there exist different opinions on whether or not communication strategies should be taught directly in the classroom, as there are strong theoretical arguments that reject the validity and usefulness of specific CS training. Taxonomy on communication strategies was developed by Dornyei \& Scott (1995). Communication strategies taxonomy by Dornyei \& Scotts (1995) are as below (Dornyei \& Scotts, 1997: 173210):

1. Avoidance Strategies: Message abandonment

2. Avoidance Strategies: Topic Avoidance

3. Compensatory Strategies: Circumlocution

4. Compensatory Strategies: Approximation

5. Compensatory Strategies: Use of all-purpose words

6. Compensatory Strategies: Word coinage

7. Compensatory Strategies: Prefabricated patterns

8. Compensatory Strategies: Non-linguistic signals

9. Compensatory Strategies: Literal translation

10. Compensatory Strategies: Foreignizing

11. Compensatory Strategies: Code-switching

12. Compensatory Strategies: Appeal for help 
13. Compensatory Strategies: Stalling or time-gaining strategies

Avoidance Strategies: Message Abandonment

\begin{tabular}{|c|c|c|}
\hline Student & Conversation & $\begin{array}{l}\text { Communication } \\
\text { Strategy Used }\end{array}$ \\
\hline S17 & $\begin{array}{l}\text { Yes, me too. I want to study here much longer if I can } \\
\text { because this mobility program is good, give me good } \\
\text { experience. You like this program? }\end{array}$ & \\
\hline S18 & $\begin{array}{l}\text { Errr...program... I like bus to campus free and room very } \\
\text { nice. }\end{array}$ & CS1 \\
\hline S17 & $\begin{array}{l}\text { No, I ask about mobility program. You like or not? Nice or } \\
\text { not nice? Enjoy not enjoy? }\end{array}$ & \\
\hline S18 & Hmm...Errr...mobility...or.... what class you have? & CS1 \\
\hline S17 & Ok, never mind. I have English class 4pm. You? & \\
\hline S18 & No class, I go home. Ok I don't know, see you, bye. & CS1 \\
\hline S1 & Okay, see you later. Bye. & \\
\hline
\end{tabular}

Table 2: Communication Strategies: Message Abandonment

Table 2 above shows the use of message abandonment as part of the communication strategy in the conversation. When someone feels uncomfortable or unsure, they tend to abandon the message given to them. This is mostly due to language difficulties faced by the subjects. For example, towards the end of the conversation, S18 was unsure of what to answer to the question asked by S17 when she stated "Errr...program... I like bus to campus free and room very nice" which shows S18 is trying to avoid the topic or the question asked as well as abandoning her message and leave it unfinished by not answering the question and changing the topic to something else. Since S18 is lack in understanding the English language, S17 had to repeat herself because $\$ 18$ was not able to answer related to the topic discussed. According to Dornyei \& Scott (1997), message abandonment means leaving a message unfinished because of language difficulties.

Avoidance Strategies: Topic Avoidance

\begin{tabular}{|c|c|c|}
\hline Student & Conversation & $\begin{array}{l}\text { Communication } \\
\text { Strategy Used }\end{array}$ \\
\hline S7 & $\begin{array}{l}\text { Yes, me too. I want to study here much longer if I can } \\
\text { because this mobility program is good, give me good } \\
\text { experience. You like this program? }\end{array}$ & \\
\hline S8 & $\begin{array}{l}\text { Errr...program... I like bus to campus free and room very } \\
\text { nice. }\end{array}$ & CS2 \\
\hline S7 & $\begin{array}{l}\text { No, I ask about mobility program. You like or not? Nice or } \\
\text { not nice? Enjoy not enjoy? }\end{array}$ & \\
\hline S8 & Hmm...Errr...mobility...or....what class you have? & CS2 \\
\hline S7 & Ok, never mind. I have English class 4pm. You? & \\
\hline S8 & No class, I go home. Ok I don't know, see you, bye. & CS2 \\
\hline S7 & Okay, see you later. Bye. & \\
\hline
\end{tabular}

Table 3: Communication Strategies: Topic Avoidance 
Table 3 above shows the use of topic avoidance as part of communication strategy in conversation. At the beginning, the conversation went well as both students understood the flow of the questions. However, towards the end, S8 was unsure of what to answer to the question asked by S7 when she stated "Errr...program... I like bus to campus free and room very nice" which shows $\mathbf{S 8}$ is trying to avoid the topic or question asked as well as abandoning her message and leave it unfinished by not answering it and changing the topic to something else. Since S8 is lack in understanding the English language, S7 had to repeat herself because S8 was not able to answer related to the topic discussed. According to Dornyei \& Scott (1997), topic avoidance means avoiding topic areas or concepts that pose language difficulties.

Compensatory Strategies: Circumlocution

\begin{tabular}{|l|l|l|}
\hline Student & Conversation & $\begin{array}{l}\text { Communication } \\
\text { Strategy Used }\end{array}$ \\
\hline S12 & $\begin{array}{l}\text { If can I want stay here longer but my family not rich. } \\
\text { Cannot afford to pay me study here long time. }\end{array}$ & CS3 \\
\hline S11 & $\begin{array}{l}\text { Yes, me too. I want to study here much longer if I can } \\
\text { because this mobility program is good, give me good } \\
\text { experience. You like this program? }\end{array}$ & CS3 \\
\hline S11 & $\begin{array}{l}\text { No, I ask about mobility program. You like or not? Nice or } \\
\text { not nice? Enjoy not enjoy? }\end{array}$ & CS3 \\
\hline
\end{tabular}

Table 4: Communication Strategies: Circumlocution

Table 4 above shows the use of circumlocution as a communication strategy in conversations. The subjects tend to get more comfortable and trust the other person that they are having a conversation with and would start to talk and elaborate more on their answers which shows the conversation getting more interesting and fun. Since S12 lack in understanding of the English language, S11 had to repeat herself because S12 was not able to answer the question related to the topic discussed. S11 had to use other alternative term to explain her question to S12 in order to make the conversation more understandable by S12 when S11 mentioned "No, I ask about mobility program. You like or not? Nice or not nice? Enjoy not enjoy?". Further explanation was given by both S11 and S12 in order to further describe or explain about their situation or action during the conversation when both stated "If can I want stay here longer but my family not rich. Cannot afford to pay me study here long time" and "Yes, me too. I want to study here much longer if I can because this mobility program is good, give me good experience. You like this program?". According to Dornyei \& Scott (1997), circumlocution means the need to describe in details of a target action.

Compensatory Strategies: Approximation

\begin{tabular}{|c|c|c|}
\hline Student & Conversation & $\begin{array}{l}\text { Communication } \\
\text { Strategy Used }\end{array}$ \\
\hline S20 & $\begin{array}{l}\text { Errr...program... I like bus to campus free and room very } \\
\text { nice. }\end{array}$ & \\
\hline S19 & $\begin{array}{l}\text { No, I ask about mobility program. You like or not? Nice } \\
\text { or not nice? Enjoy not enjoy? }\end{array}$ & CS4 \\
\hline S20 & Hmm...Errr...mobility...or....what class you have? & \\
\hline
\end{tabular}

Table 5: Communication Strategies: Approximation 
Table 5 above shows the use of approximation as communication strategy in the subjects' conversation. Sometimes in a conversation, there is a need to use alternative term in order to express the meaning of a certain word or situation and it is described as closely as possible to match the understanding of the other person. For example, since S20 is lack in understanding the English language, S19 had to repeat herself because S20 was not able to answer related to the topic discussed. S19 had to use other alternative term to explain her question to S20 in order to make the conversation more understandable by S20 when S19 mentioned "No, I ask about mobility program. You like or not? Nice or not nice? Enjoy not enjoy?".

Compensatory Strategies: Non-linguistic Signals

\begin{tabular}{|l|l|l|}
\hline Student & Conversation & $\begin{array}{l}\text { Communication } \\
\text { Strategy Used }\end{array}$ \\
\hline S15 & $\begin{array}{l}\text { Hey that's the same faculty with me. But I take Economics. } \\
\text { But we are still in the same faculty. Maybe I have seen you } \\
\text { before, but I don't really remember. UPM is huge with so } \\
\text { many students, so I can't recognize everyone. Hahaha }\end{array}$ & CS8 \\
\hline S16 & $\begin{array}{l}\text { Yes, that is true. So many student at our faculty right? } \\
\text { Maybe I see you before too. }\end{array}$ & \\
\hline
\end{tabular}

Table 6: Communication Strategies: Non-linguistic Signals

Table 6 above shows the use of non-linguistic signals by S15 in her conversation. S15 was happy to express her feelings to S16 and at the end of the conversation, S15 just laughed when she thought it was funny being in the same faculty as S16 but have never met S16 before all the while. Non-linguistic signals are commonly used by a lot of people when communicating with each other as it includes mime, gesture, facial expression or sound imitation.

Compensatory Strategies: Foreignizing

\begin{tabular}{|l|l|l|}
\hline Student & Conversation & $\begin{array}{l}\text { Communication } \\
\text { Strategy Used }\end{array}$ \\
\hline S12 & $\begin{array}{l}\text { No I mean do you practice speak English more with your } \\
\text { friends here? Errr...Yes Malaysia is very hot, sometimes } \\
\text { too hot. }\end{array}$ & $\begin{array}{l}\text { But I like 'jalan-jalan' in Malaysia. Many good nice place I } \\
\text { go. }\end{array}$ \\
\hline S11 & $\begin{array}{l}\text { Even hot but Malaysia have very nice place to visit...Yes } \\
\text { jalan-jalan' very good. }\end{array}$ & CS10 \\
\hline S12
\end{tabular}

Table 7: Communication Strategies: Foreignizing

Table 7 above shows the use of foreignizing as a communication strategy in a conversation. It can be seen that both S11 and S12 use foreign language in their conversation when they mentioned "But I like 'jalan-jalan' in Malaysia. Many good nice place I go" and "Even hot but Malaysia have very nice place to visit...Yes 'jalan-jalan' very good" which show the use of a foreign language besides English to communicate, as it is an L3 understood by both of them. According to Dornyei \& Scott (1997), foreignizing means using a L1 word by adjusting it to L2 phonology and / or morpholy. 
Compensatory Strategies: Appeal for help

\begin{tabular}{|l|l|l|}
\hline Student & Conversation & $\begin{array}{l}\text { Communication } \\
\text { Strategy Used }\end{array}$ \\
\hline S5 & Errr..What else to say...I'm not sure.. & CS12 \\
\hline S6 & Hmm..I not sure too... & CS12 \\
\hline
\end{tabular}

Table 8: Communication Strategies: Foreignizing

Table 8 above shows the use of appeal for help as a communication strategy for most pair conversations. When you ran out of idea on what else to talk about, you tend to ask for help from the other person to give an idea on what else can be discussed about or if there is a new topic the other person may have in mind. They might feel lost and not knowing what to do and what to say next, therefore the best way is to seek for help so that the conversation does not go blank or awkward. S5 and S6 were feeling lost a little bit towards the end of the conversation which led to both students asking each other on what else to be discussed about when they mentioned "Errr..What else to say...I'm not sure.." and "Hmm..I not sure too...". According to Dornyei \& Scott (1997), appeal for help means asking for aid from the interlocutor either directly or indirectly.

Compensatory Strategies: Stalling or time-gaining strategies

\begin{tabular}{|c|c|c|}
\hline Student & Conversation & $\begin{array}{l}\text { Communication } \\
\text { Strategy Used }\end{array}$ \\
\hline S4 & $\begin{array}{l}\text { For me I have language problem here. I cannot } \\
\text { understand } 100 \% \text { but I can understand } 60 \text { to } 70 \% \text { but I } \\
\text { like my class. }\end{array}$ & \\
\hline S3 & $\begin{array}{l}\text { Now okay...maybe...lucky I stay here } 2 \text { semester practice } \\
\text { more speaking English. }\end{array}$ & CS13 \\
\hline S4 & $\begin{array}{l}\text { Yes, same with me I stay here } 2 \text { semester and very good } \\
\text { my English getting better to understand. You practice } \\
\text { more with you friends? }\end{array}$ & \\
\hline
\end{tabular}

Table 9: Communication Strategies: Stalling or time-gaining strategies

Table 9 above shows the use of stalling or time-gaining strategies as a communication strategy in a conversation. Stalling and time-gaining strategies are commonly used in most conversations everywhere. Examples can be seen in the conversation when S3 uses "...maybe..". Subjects tend to use this strategy to give them time to think about what to say or how to respond back to a question given to them without making the situation go awkward with the other person. According to Dornyei \& Scott (1997), stalling or time-gaining strategies is defined as using filters or hesitation devices to fill pauses and to gain time to think.

\section{Conclusion}

In conclusion, it can be seen that majority of the students used communication strategies in their conversation. It is known that all the subjects are from a none English speaking country, therefore the need to use communication strategies in their communication are critical. The result of this study shows that the use of communication strategies among students from none English speaking country are curial are can be obviously seen. The result of the study is also in line with the objective of the study on identifying the use of communication strategies among inbound mobility students from a none English speaking country who are studying at 
Universiti Putra Malaysia. It is also clearly stated that the use of variety of communication strategies are needed among these students in order to communicate in English. This is in line with a study by Masithoh \& Fauziati (2018) whereby speakers and listeners need to find an effective way to communicate in English and their thoughts to showcase the importance of the English speaking skills as it helps to cope with the various communicative situations and used to compensate the learners' inadequacies so that they can survive in their communication in the chosen language. This is consistent with a study by Vettorel (2018) that indicates communication strategies have shown a significant role in English as a Lingua Franca communication, which is characterised by negotiation and co-construction of meaning; in these encounters, where different linguacultural meet, ELF speakers employ a range of pragmatic strategies to solve, or pre-empt, (potential) non-understandings often drawing on their plurilingual repertoires. With this, it shows that communication strategies play a big role towards the fundamentals of the English language, especially when English is used as a Lingua France. This is agreeable to support a study by Nizar, Nitiasih \& Suarnajaya (2018), as an EFL country, English Language Teaching (ELT) should be more focused on developing students' strategy especially in their communication strategy (CS). The reason is because these students are triggered by instrumental motivation in learning English. However, awareness toward CS should also be implemented by teachers so they can develop students' communication strategies through their chosen ways of teaching. Unfortunately, it is rarely found English teacher who is aware about this notion. This is also in line with a study by Rofiatun (2018), communication strategies were used to improve students' speaking ability and encourage them to communicate in English.

In this study, only 9 communication strategies were used from Dornyei \& Scott (1997) communication strategy theory and they are Avoidance Strategies: Message abandonment, Topic avoidance, Compensatory Strategies: Circumlocution, Approximation, Prefabricated patterns, Non-linguistic signals, Literal translation, Foreignizing, Code-switching, Appeal for help and Stalling or time-gaining strategies. This is because only these 9 strategies are relevant and related to the communication strategies mainly used by both pair and small group subjects in their conversations when communicating. The other 4 communication strategies are rarely used in most conversation therefore it is not analysed in this study which are Use of all-purpose words, prefabricated patterns, literal translation and code-switching because these 4 strategies. This is in line with a study by Wan et. al. (2014) where learners' use of CSs is influenced by a variety of factors, among which the development stage of their interlanguage and their cultural background are identified as two important factors. 


\section{References}

Adnett, N. (2010). The growth of international students and economic development: Friends or foes? Journal of Education Policy, 25, 625-637.

Al Hosni, S. (2014). Speaking difficulties encountered by young EFL learners. International Journal on Studies in English Language and Literature (IJSELL), 2(6), 22-30.

Khan, A. M. (2017). Strategies to Overcome Barriers in Communication. Unpublished Master's Thesis.

Bagnoli, A. (2009). On 'An Introspective Journey': Identities and Travel In Young People's Lives. European Societies, 11, 325-345.

Beech, S. E. (2014). Why Place matters: Imaginative Geography and International Student Mobility. Area, 46, 170-177.

Brooks, R., \& Waters, J. (2010). Social networks and educational mobility: The experiences of UK students. Globalisation Societies and Education, 8, 143-157.

Brooks, R., \& Waters, J. (2011). Student mobilities, migration and the internationalization of higher education. Basingstoke: Palgrave Macmillan.

Cairns, D. (2018). Researching Social Inclusion in Student Mobility: Methodological Strategies in Studying The Erasmus Programme. International Journal of Research \& Method in Education. https://doi.org/10.1080/1743727X.2018.1446928

De Wit, H., \& Hunter, F. (2015). Understanding Internationalisation of Higher Education In The European Context. In de Wit, H., Hunter, F., Howard, L. and Egron-Polak, E. (eds.), Internationalisation of Higher Education. Brussels: European Parliament, 41 58.

Dörnyei, Z., \& Scott, M. (1997). Communication Strategies in a Second Language Definitions and Taxonomies. Language Learning, 47 (1), 173-209.

European Erasmus. (2018). Erasmus-Facts, Figures \& Trends. The European Union Support or Student and Staff Exchanges and University Cooperation, 13.

Floyd, K. (2008). Human Communication. Cresskill. NJL Hampton Press.

Foster, M. (2017). Exploring the Impact of International Student Mobility on Cross Cultural Learning Adaptation. In: Teh G., Choy S. (eds) Empowering $21^{\text {st }}$ Century Learners Through Holistic and Enterprising Learning. Springer, Singapore.

Masitho, H., Fauziati, E., \& Supriyadi, S. (2018). Communication Strategies Used by the Students on the Perspective of Language Proficiency. International Journal of Multicultural and Multireligious Understanding, 5(5).

Manjet Kaur Mehar Singh. (2016). An Emic Perspective on Academic Writing Difficulties among International Graduate Students in Malaysia. GEMA Online ${ }^{\circledR}$ Journal of Language Studies Volume 16(3), ISSN: 1675-8021 83.

Masithoh, H., \& Fauziati, E. (2018). Communication Strategies Used by the Students on the Perspective of Language Proficiency. International Journal of Multicultural and Multireligious Understanding. 5, (5), 21-32.

Nakatani, Y. (2010). Identifying Strategies That Facilitate EFL Learners' Oral Communication: A Classroom Study Using Multiple Data Collection Procedures. The Modern Language Journal, 94(1), 346-8512.

Roslan, N. R., Abdul Jabar, M. A., Halim, H. A., \& Shamshudeen, R. I. (2018). Students' Perception towards Short Term Mobility Program. Infrastructure University Kuala Lumpur Research Journal. 6(1).

Rhoades, G. (2017). Backlash Against "Others". International Higher Education, 89, 2-3. 
Rochester, N. (2018). The Seven Biggest Challenges of Effective Communications. Retrieved on April 2019 https://www.strategyex.co.uk/blog/pmoperspectives/theseven-biggest -challenges-to-effective-communication/

Rofiatun, I. (2018). Communication Strategies Used by English Teacher in Teaching and Learning Process. 2nd English Language and Literature International Conference (ELLiC) Proceedings- (ELLiC Proceedings), 2.

Sawir, E., Marginson, S., Forbes-Mewett, H., Nyland, C., \& Ramia, G. (2012). International Student Security and English Language Proficiency. Journal of Studies in International Education. DOI: https://doi.org/10.1177/1028315311435418

Khullar, V. (2017). How Do Language Barriers Affect Communication? Retrieved 28 August 2018 from https://www.quora.com/How-do-language-barriers-affectcommunication

Vettorel, P. (2018). ELF and Communication Strategies: Are They Taken into Account in ELT Materials? University of Verona, Italy. RELC Journal, Vol. 49(1) 58-73. DOI: $10.1177 / 0033688217746204$.

Wan, D., Lai, H., \& Leslie, M. (2014). Chinese English Learners' Strategic Competence. Journal of Psycholinguistics Research.

Wood, V. G. (2010). International Communication Barriers. American Journal of Orthopsychiatry, 33, 233-234. doi: 10.1111/j.1939-0025.1963.tb03781.x 


\section{Appendices}

Avoidance Strategies: Message Abandonment

\begin{tabular}{|c|c|c|}
\hline Student & Conversation & $\begin{array}{l}\text { Communication } \\
\text { Strategy Used }\end{array}$ \\
\hline S17 & $\begin{array}{l}\text { Yes, me too. I want to study here much longer if I can } \\
\text { because this mobility program is good, give me good } \\
\text { experience. You like this program? }\end{array}$ & \\
\hline S18 & $\begin{array}{l}\text { Errr...program... I like bus to campus free and room very } \\
\text { nice. }\end{array}$ & CS1 \\
\hline S17 & $\begin{array}{l}\text { No, I ask about mobility program. You like or not? Nice or } \\
\text { not nice? Enjoy not enjoy? }\end{array}$ & \\
\hline S18 & Hmm...Errr...mobility...or....what class you have? & CS1 \\
\hline S17 & Ok, never mind. I have English class 4pm. You? & \\
\hline S18 & No class, I go home. Ok I don't know, see you, bye. & CS1 \\
\hline S1 & Okay, see you later. Bye. & \\
\hline
\end{tabular}

Avoidance Strategies: Topic Avoidance

\begin{tabular}{|l|l|l|}
\hline Student & Conversation & $\begin{array}{l}\text { Communication } \\
\text { Strategy Used }\end{array}$ \\
\hline S7 & $\begin{array}{l}\text { Yes, me too. I want to study here much longer if I can } \\
\text { because this mobility program is good, give me good } \\
\text { experience. You like this program? }\end{array}$ & \\
\hline S8 & $\begin{array}{l}\text { Errr...program... I like bus to campus free and room very } \\
\text { nice. }\end{array}$ & CS2 \\
\hline S7 & $\begin{array}{l}\text { No, I ask about mobility program. You like or not? Nice or } \\
\text { not nice? Enjoy not enjoy? }\end{array}$ & \\
\hline S8 & Hmm...Errr...mobility...or....what class you have? & CS2 \\
\hline S7 & Ok, never mind. I have English class 4pm. You? & CS2 \\
\hline S8 & No class, I go home. Ok I don't know, see you, bye. & \\
\hline S7 & Okay, see you later. Bye. &
\end{tabular}

Compensatory Strategies: Circumlocution

\begin{tabular}{|l|l|l|}
\hline Student & Conversation & $\begin{array}{l}\text { Communication } \\
\text { Strategy Used }\end{array}$ \\
\hline S12 & $\begin{array}{l}\text { If can I want stay here longer but my family not rich. } \\
\text { Cannot afford to pay me study here long time. }\end{array}$ & CS3 \\
\hline S11 & $\begin{array}{l}\text { Yes, me too. I want to study here much longer if I can } \\
\text { because this mobility program is good, give me good } \\
\text { experience. You like this program? }\end{array}$ & CS3 \\
\hline S11 & $\begin{array}{l}\text { No, I ask about mobility program. You like or not? Nice or } \\
\text { not nice? Enjoy not enjoy? }\end{array}$ & CS3 \\
\hline
\end{tabular}


Compensatory Strategies: Approximation

\begin{tabular}{|l|l|l|}
\hline Student & Conversation & $\begin{array}{l}\text { Communication } \\
\text { Strategy Used }\end{array}$ \\
\hline S20 & $\begin{array}{l}\text { Errr...program... I like bus to campus free and room very } \\
\text { nice. }\end{array}$ & \\
\hline S19 & $\begin{array}{l}\text { No, I ask about mobility program. You like or not? Nice } \\
\text { or not nice? Enjoy not enjoy? }\end{array}$ & CS4 \\
\hline S20 & Hmm...Errr...mobility...or.....what class you have? & \\
\hline
\end{tabular}

Compensatory Strategies: Appeal for help

\begin{tabular}{|l|l|l|}
\hline Student & Conversation & $\begin{array}{l}\text { Communication } \\
\text { Strategy Used }\end{array}$ \\
\hline S5 & Errr..What else to say...I'm not sure.. & CS12 \\
\hline S6 & Hmm..I not sure too... & CS12 \\
\hline
\end{tabular}

Compensatory Strategies: Stalling or time-gaining strategies

\begin{tabular}{|l|l|l|}
\hline Student & Conversation & $\begin{array}{l}\text { Communication } \\
\text { Strategy Used }\end{array}$ \\
\hline S4 & $\begin{array}{l}\text { For me I have language problem here. I cannot } \\
\text { understand } 100 \% \text { but I can understand } 60 \text { to } 70 \% \text { but I } \\
\text { like my class. }\end{array}$ & $\begin{array}{l}\text { Now okay...maybe...lucky I stay here 2 semester practice } \\
\text { more speaking English. }\end{array}$ \\
\hline S3 & $\begin{array}{l}\text { Yes, same with me I stay here 2 semester and very good } \\
\text { my English getting better to understand. You practice } \\
\text { more with you friends? }\end{array}$ & \\
\hline S4
\end{tabular}

